\title{
The midgut of Aedes albopictus females expresses active trypsin-like serine peptidases
}

Leonardo Saboia-Vahia ${ }^{1}$, Patricia Cuervo², Andre Borges-Veloso ${ }^{1}$, Nathália Pinho de Souza², Constança Britto ${ }^{1}$, Geovane Dias-Lopes ${ }^{1}$ and Jose Batista De Jesus ${ }^{1,3^{*}}$

\begin{abstract}
Background: Aedes albopictus is widely distributed across tropical and sub-tropical regions and is associated with the transmission of several arboviruses. Although this species is increasingly relevant to public health due its ability to successfully colonize both urban and rural habitats, favoring the dispersion of viral infections, little is known about its biochemical traits, with all assumptions made based on studies of $A$. aegypti. In previous studies we characterized the peptidase profile of pre-imaginal stages of $A$. albopictus and we reported the first proteomic analysis of the midgut from sugar-fed females of this insect species.

Methods: In the present work, we further analyzed the peptidase expression in the midgut of sugar-fed females using 1DE-substrate gel zymography, two-dimensional electrophoresis (2DE), mass spectrometry (MS), and protein identification based on similarity.

Results: The combination of zymography, in solution assays using fluorescent substrates and 2DE-MS/MS allowed us to identify the active serine peptidase "fingerprint" in the midgut of A. albopictus females. Zymographic analysis revealed a proteolytic profile composed of at least 13 bands ranging from $\sim 25$ to $250 \mathrm{kDa}$, which were identified as trypsin-like serine peptidases by using specific inhibitors of this class of enzymes. Concomitant use of the fluorogenic substrate Z-Phe-Arg-AMC and trypsin-like serine protease inhibitors corroborated the zymographic findings. Our proteomic approach allowed the identification of two different trypsin-like serine peptidases and one chymotrypsin in protein spots of the alkaline region in 2DE map of the A. albopictus female midgut. Identification of these protein coding genes was achieved by similarity to the $A$. aegypti genome sequences using Mascot and OMSSA search engines.

Conclusion: These results allowed us to detect, identify and characterize the expression of active trypsin-like serine peptidases in the midgut of sugar-fed A. albopictus females. In addition, proteomic analysis allowed us to confidently assign the expression of two trypsin genes and one chymotrypsin gene to the midgut of this mosquito. These results contribute to the gene annotation in this species of unknown genome and represent a small but important step toward the protein-level functional and localization assignment of trypsin-like serine peptidase genes in the Aedes genus.
\end{abstract}

Keywords: Aedes albopictus, Culicidae, Midgut, Zymography, Proteomics, Two-dimensional electrophoresis, Mass spectrometry

\footnotetext{
* Correspondence: jbj@ioc.fiocruz.br

${ }^{1}$ Laboratório de Biologia Molecular e Doenças Endêmicas, Instituto Oswaldo Cruz, FIOCRUZ, Rio de Janeiro, Brazil

${ }^{3}$ Universidade Federal de São João del Rei, São João del Rei, MG, Brazil

Full list of author information is available at the end of the article
}

\section{Biomed Central}

(c) 2014 Saboia-Vahia et al.; licensee BioMed Central Ltd. This is an Open Access article distributed under the terms of the Creative Commons Attribution License (http://creativecommons.org/licenses/by/2.0), which permits unrestricted use, distribution, and reproduction in any medium, provided the original work is properly credited. 


\section{Background}

Aedes (Stegomyia) albopictus (Skuse) has a wide geographic distribution, covering all tropical and subtropical regions of the world, and is a vector for the viruses responsible for yellow fever and dengue [1]. The World Health Organization estimates that more than 50-100 million cases of these two diseases can occur per year throughout the world [2-4]. In Brazil, A. albopictus has been reported in 21 states and 1,502 municipalities [5]. In recent years, the relevance of this species to public health has increased because it is able to successfully colonize both urban and rural habitats, favoring the dispersion and interchange of the virus from one area to another, and thereby enabling the emergence of new areas of disease in small and large cities [6,7].

The hydrolysis of proteins to amino acid residues by proteolytic enzymes is an important step in food digestion, protein turnover and proteostasis in eukaryotes $[8,9]$. Proteolytic enzymes are divided into endopeptidases and exopeptidases. Endopeptidases are relatively small molecules $(\sim 25-30 \mathrm{kDa})$ that can pass through peritrophic membrane pores and endoperitrophic spaces in insects, where they cleave large protein complexes. Exopeptidases are large enzymes $(>100 \mathrm{kDa})$ that are usually linked to the plasma membrane of the midgut epithelium and hydrolyze the ends of small proteins and peptides ( $\mathrm{N}$-terminus or C-terminus) [10]. Among endopeptidases, trypsin-like and chymotrypsin-like serine peptidases are the most important enzymes for most insects, except for some species of coleoptera and hemiptera [11-16].

Serine peptidases are divided into families and subfamilies. The subfamily S1 consists of trypsins, chymotrypsins and elastases, and some serine collagenases were also recently included. The catalytic triad of serine peptidases is typically characterized by serine, histidine and aspartic acid residues $[17,18]$. This triad hydrolyzes peptide bonds at the carboxylic ends of basic amino acids, with a 2-10-fold preference for Arg over Lys [19-21]. The A. aegypti genome contains 369 genes coding for serine peptidases, among which 66 are putative trypsins [22], but only 5 (three trypsins and two chymotrypsins) are well characterized in the midgut of females of this insect [13-16,23]. The expansion of trypsin-like serine peptidase genes in mosquitoes has been shown to coincide with the development of the hematophagous trait [24]. Trypsinlike serine peptidases in these insects play pivotal roles in oogenesis, immunity, metamorphosis, modulation of embryonic development and nutrition $[25,26]$. These enzymes are mostly located in the insect midgut so that they can provide energy and essential amino acids for development $[20,27]$. Furthermore, secretion of trypsinlike serine peptidases into the lumen of the midgut is involved in defense against pathogens $[28,29]$. However, in the insect vector Anopheles gambiae, trypsin-like enzymes are exploited by pathogens such as Plasmodium sp. to activate their own peptidases, thus allowing the parasite to cross the peritrophic membrane and continue its developmental life cycle [30].

The plasticity exhibited by trypsin-like serine peptidases enables these enzymes to modulate various biological processes in insect vectors. Because of this characteristic, serine peptidases have been proposed as potential targets for insect control approaches. The biochemical characterization of these enzymes may thus support the development of new control strategies, enabling their appropriate use as targets and suggesting ways to interfere with the production of these enzymes or with the metabolic pathways in which they participate [31,32].

In previous studies, we characterized the peptidase profile of the pre-imaginal stages of A. albopictus [33] and reported the first proteomic analysis of the midgut of sugar-fed females of this insect species [33]. In the present work, we further analyze the peptidase expression in the midgut of sugar-fed females using two-dimensional electrophoresis (2DE), mass spectrometry, 1DE-substrate gel, and data mining. This multi-methodological approach allowed us to identify the active serine peptidase "fingerprint" in the midgut of $A$. albopictus females.

\section{Methods}

\section{Chemicals}

To prepare the phenylmethylsulfonylfluoride (PMSF) stock solution, $250 \mathrm{mM}$ of the reagent was diluted in isopropanol. N $\alpha$-tosyl-L-lysine chloromethyl ketone hydrochloride (TLCK) and N-p-tosyl-L-phenylalanine chloromethyl ketone (TPCK) were dissolved in methanol, both at $100 \mathrm{mM}$. Stock solutions of 1,10-phenanthroline $(200 \mathrm{mM})$ and pepstatin A $(1 \mathrm{mg} / \mathrm{ml})$ were prepared in ethanol, and transepoxysuccinyl L-leucylamido-(4-guanidino) butane (E-64, $10 \mathrm{mM}$ ) was prepared in water. Stock and working solutions were maintained at $-20^{\circ} \mathrm{C}$. All chemicals were purchased from Sigma Chem. Co. (USA), unless otherwise specified.

\section{Insect rearing and gut dissection}

Aedes albopictus specimens reared in a closed colony (Laboratório de Transmissores de Hematozoários, Instituto Oswaldo Cruz, FIOCRUZ, Rio de Janeiro) were kindly provided by Dr. Nildimar A. Honorio. Mosquitoes were maintained on a $10 \%$ sucrose diet at $25 \pm 1^{\circ} \mathrm{C}$, with a relative humidity of $60 \pm 10 \%$ and a light:dark photoperiod of 14:10 h. For each experiment, 50 female adults (2-5 days old) were cold-anesthetized on ice and decapitated. Midgut dissection was performed as previously described [33].

\section{Zymography and peptidase inhibition assays}

For proteolytic assessment, midguts were washed twice with PBS pH 7.2 and lysed as previously described [33]. 
Briefly, midguts were lysed with a cell disruption motor drive and pestle in a tube containing $10 \%$ glycerol, $0.6 \%$ Triton X-100, $100 \mathrm{mM}$ Tris- $\mathrm{HCl} \mathrm{pH} 6.8$ and $150 \mathrm{mM}$ $\mathrm{NaCl}$ [34]. The protein concentration of the resulting extracts was determined using the Pierce $660 \mathrm{~nm}$ Protein assay (Thermo Scientific). For protein separation, $30 \mu \mathrm{g}$ of protein were loaded in $12 \%$ polyacrylamide gels copolymerized with $0.1 \%$ porcine gelatin as the substrate. Electrophoreses were performed at $4{ }^{\circ} \mathrm{C}$ with a constant voltage of $110 \mathrm{~V}$. Peptidase activity was detected as previously reported [33] with few modifications. The gels were incubated at $37^{\circ} \mathrm{C}$ for $2,4,6,12$ or $24 \mathrm{~h}$ in reaction buffer containing $100 \mathrm{mM}$ sodium acetate (at pH 3.5 or 5.5) or $100 \mathrm{mM}$ Tris-HCl (pH 7.5 or 10.0). Substrate degradation was visualized as clear bands after staining the gels with $0.2 \%$ Coomassie blue R-250 in methanol/ acetic acid (40:10) and destaining in 10\% acetic acid. The relative molecular masses of the activity bands were estimated by comparison with the mobility of a commercial molecular mass standard (PageRuler ${ }^{\text {rm }}$ Protein Ladder, Fermentas). To determine the classes of peptidases detected by zymography, peptidase inhibition assays were conducted. Midgut homogenates were pre-incubated (before electrophoresis) for $30 \mathrm{~min}$ at $4^{\circ} \mathrm{C}$ with one of the following peptidase inhibitors: $20 \mu \mathrm{M} \mathrm{E}-64,5 \mathrm{mM}$ PMSF, $100 \mu \mathrm{M}$ TLCK, $100 \mu \mathrm{M}$ TPCK, $10 \mu \mathrm{M}$ pepstatin-A or $10 \mathrm{mM}$ 1,10-phenanthroline. After electrophoresis, inhibitors were added to the reaction buffer at the same concentration, and the peptidases were resolved as described above. The results were derived from three independent experiments carried out in triplicate.

\section{In-solution enzymatic assays}

The effects of $\mathrm{pH}$ and peptidase inhibitors on the proteolytic activities of midgut homogenates were also evaluated by in-solution assays using the fluorogenic substrate Z-Phe-Arg-AMC. For both assays, $100 \mu \mathrm{M}$ of substrate was used. The reactions were initiated by diluting $10 \mu \mathrm{g}$ of protein from the midgut in $100 \mathrm{mM}$ sodium acetate (at $\mathrm{pH} 3.5$ or 5.5$)$ or $100 \mathrm{mM}$ Tris- $\mathrm{HCl}(\mathrm{pH} 7.5$ or 10.0) for $\mathrm{pH}$ evaluation or $100 \mathrm{mM}$ Tris- $\mathrm{HCl} \mathrm{pH} 7.5$ with or without $100 \mu \mathrm{M}$ TLCK, $100 \mu \mathrm{M}$ TPCK, $20 \mu \mathrm{M}$ E-64 or $5 \mathrm{mM}$ PMSF. The fluorescence intensity was measured by spectrophotofluorometry every $5 \mathrm{~min}$ for a $60 \mathrm{~min}$ period (SpectraMax Gemini XPS, Molecular Devices, CA) using excitation and emission wavelengths of 380 and $460 \mathrm{~nm}$, respectively. As blank, the substrate $(100 \mu \mathrm{M})$ was diluted in the reaction buffer $[100 \mathrm{mM}$ sodium acetate (at pH 3.5 or 5.5) or $100 \mathrm{mM}$ Tris- $\mathrm{HCl}$ ( $\mathrm{pH} 7.5$ or 10.0)]. The value of the blank was automatically discounted by the fluorometer software (SoftMax Pro, Molecular Devices, $\mathrm{CA})$ when the data were acquired. All assays were performed at $37^{\circ} \mathrm{C}$. The results were derived from three independent experiments performed in triplicate.

\section{DE electrophoresis and protein identification}

Protein extraction, separation and identification were performed as previously described [33]. Briefly, 50 pooled midguts were mechanically disrupted with a pestle and a motor drive in a tube containing lysis buffer $(9 \mathrm{M}$ urea, 4\% CHAPS, $65 \mathrm{mM}$ dithiothreitol, DTT, and 1\% ampholytes, pH 3-10, with $5 \mathrm{mM}$ PMSF and a protease inhibitor cocktail). Proteins were precipitated and resuspended in $9 \mathrm{M}$ urea, 4\% CHAPS, $65 \mathrm{mM}$ DTT and 1\% ampholytes, pH 3-10 NL. The protein concentration was determined using the 2D Quant Kit (GE Healthcare), and $100 \mu \mathrm{g}$ were subjected to isoelectric focusing over a nonlinear $\mathrm{pH}$ gradient of 3-10 on a $7 \mathrm{~cm}$ strip (GE Healthcare) on an Ettan IPGphor 3 instrument (GE Healthcare). The focusing parameters were set as previously described [33]. After reduction and alkylation, proteins were separated vertically across 12\% SDS-PAGE gels using standard Tris/glycine/ SDS buffer. Gels were stained with colloidal Coomassie Brilliant Blue G-250, documented using a GS-800 ${ }^{\mathrm{mm}}$ calibrated imaging densitometer (Bio-Rad) and analyzed using PDQuest $^{\text {tw }}$ software (Bio-Rad). Experimental $\mathrm{p} I$ and $\mathrm{Mr}$ were calibrated using a select set of reliable identification landmarks distributed throughout the entire gel.

Protein digestion, peptide extraction and analysis by mass spectrometry were performed as previously described [33]. Raw MS files were converted to MGF format using Mass Matrix MS Data File converter V. 3.9 http:// www.massmatrix.net/mm-cgi/downloads.py. To maximize search sensitivity and peptidase identification, the data were searched using OMSSA [35] within the Proteomatic platform 1.2.1 [36] http://www.proteomatic.org/download. $\mathrm{html}$ and the Mascot MS/MS ion search engine (www. matrixscience.com/search_form_select.html, Matrix Science, Oxford, UK, free online version). As the genome sequences of $A$. albopictus are not available, mass spectra were searched in OMSSA against an A. aegypti database downloaded (May 2013) from UniRef100 [37] http://www. uniprot.org/, and in MASCOT against the non-redundant database of the National Center for Biotechnology (NCBI). Searches were performed with one missed cleavage, with carbamidomethylation of cysteine residues as a fixed modification, methionine oxidation as a variable modification and mass tolerances of 2.0 and $0.8 \mathrm{Da}$ in OMSSA and $10 \mathrm{ppm}$ and $0.4 \mathrm{Da}$ in MASCOT for precursor and fragment ions, respectively. The Vectorbase database (www.vectorbase.org) was used to search for sequence information about the identified peptidases.

\section{Results and discussion}

\section{The $A$. albopictus female midgut exhibits a complex} profile of active peptidases

To evaluate the influence of time on the peptidase activities from the midguts of sugar-fed females, we evaluated the proteolytic profiles after 2, 4, 612 and $24 \mathrm{~h}$ of 
incubation at $37^{\circ} \mathrm{C}$ in $\mathrm{pH} 7.5$ using $1 \mathrm{D}$ zymography (Figure 1). The proteolytic profile is composed of at least 13 bands displaying progressive increases in intensity from 2 to $24 \mathrm{~h}$ of incubation. However, the proteolytic bands overlapped at $24 \mathrm{~h}$ and for this reason, $12 \mathrm{~h}$ was chosen for subsequent analyses. The band size range from $\sim 25$ to $250 \mathrm{kDa}$. The proteolytic activities of this mosquito have received little study, focusing mainly on larval activities and on comparisons with A. aegypti [38]. Comparisons between the previously reported peptidase profiles from the larval and pupal stages of $A$. albopictus [33] with the profile from the adult midgut obtained here reveals a similar banding pattern of enzymatic activity, suggesting that the peptidases expressed as part of the adult proteolytic machinery are already expressed in the pre-imaginal stages, where they mainly seem to play roles in digestion. Given that this work studied sugar-fed females, the proteolytic profile detected here is likely constitutively expressed by the mosquito throughout its life cycle. The enzymatic activity profile of the adult midgut was more complex after $12 \mathrm{~h}$ of reaction compared with the profile previously described for larvae [33] detected after $2 \mathrm{~h}$ of reaction, suggesting that these enzymes are expressed at lower levels in the adult stage of this insect. In fact, a reduction in the expression of active peptidases involved in digestion after the last larval ecdysis has been reported for $A$. aegypti and $A$. albopictus using in-solution assays and total protein extracts $[39,40]$. In sugar-fed females of $A$. aegypti, the expression of trypsin-like serine peptidases at the transcriptional level ("early trypsin")

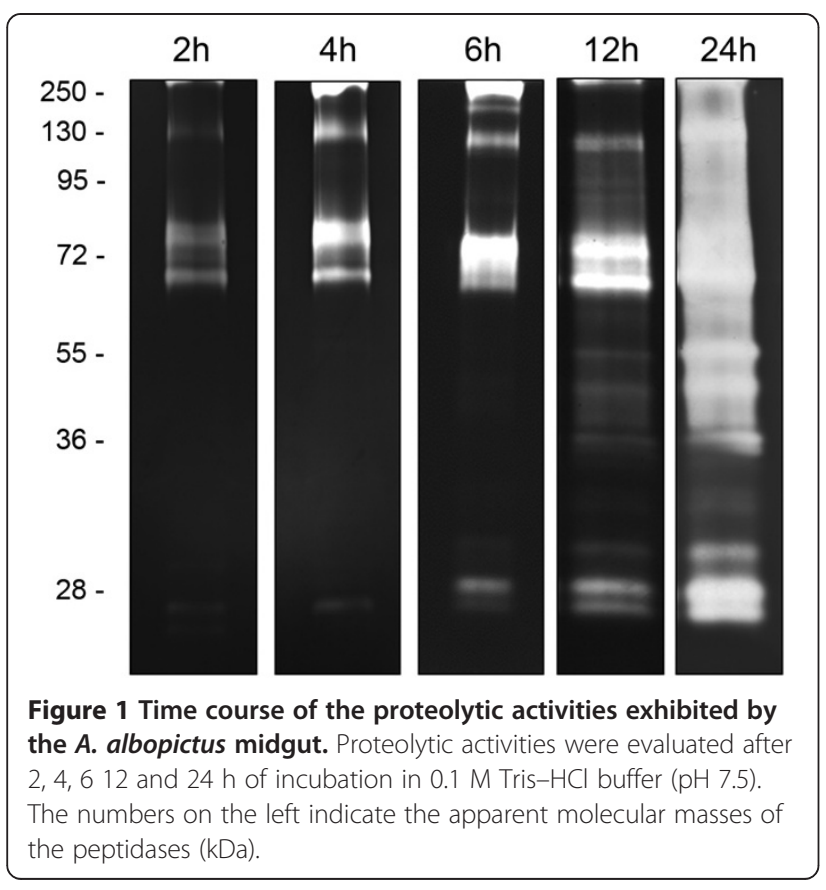

has been associated with the activation of other digestive enzymes or other trypsin isoforms that will only be expressed after the ingestion of a blood meal $[23,27,41]$. In addition, although transcriptomic analysis of $A$. aegypti revealed that adults exclusively express 15 trypsin genes while larvae express 12 , both stages share the expression of 39 trypsin coding genes, and the genes expressed by larvae should be more active than those of adults because larvae are constantly feeding [22]. Given the taxonomic proximity between $A$. albopictus and A. aegypti, trypsin expression in adults of $A$. albopictus is likely similar to the expression pattern in larvae.

\section{Influence of the $\mathrm{pH}$ on the proteolytic profile of the A. albopictus midgut}

We observed that the proteolytic activities of the midgut are modulated by the $\mathrm{pH}$ of the reaction buffer. While peptidase activities were detected as low as $\mathrm{pH} 5.5$, the intensity of these activities was increased at alkaline $\mathrm{pH}$ between 7.5 and 10.0. Little activity was detected at $\mathrm{pH} 3.5$ (Figure 2A). Although the activities seem to be optimal at $\mathrm{pH}$ 10.0, several bands overlap, preventing accurate analysis. For this reason, all subsequent assays were conducted at $\mathrm{pH}$ 7.5. The effect of $\mathrm{pH}$ on peptidase activity was corroborated by in-solution assays using fluorogenic substrates (Figure 2B). Similar to data obtained previously for larval instars and pupae [33], peptidases from the A. albopictus adult midgut exhibited optimal activities at alkaline $\mathrm{pH}$. This characteristic has also been observed for other Diptera such as Culex quinquefasciatus [5] and L. longipalpis [42] using both in-gel and in-solution assays. According to previous reports, the activities of enzymes involved in digestion processes are optimal at alkaline $\mathrm{pH}$ [37-39]. Therefore, the data obtained here suggest that the proteolytic activities observed in the midgut are mainly involved in nutrient processing.

\section{Proteolytic activities in the $A$. albopictus female midgut mainly arise from trypsin-like serine peptidases}

Inhibition assays were conducted using specific peptidase inhibitors to ascertain the classes of peptidase activities detected in the midgut of $A$. albopictus females. The proteolytic activities were inhibited by $1 \mathrm{mM}$ PMSF and $100 \mu \mathrm{M}$ TLCK (Figure 3A). The zymographic profile was not affected by $100 \mu \mathrm{M}$ TPCK, $10 \mu \mathrm{M}$ E-64 (Figure 3A), $10 \mu \mathrm{M}$ pepstatin A or $10 \mathrm{mM}$ 1,10-phenanthroline (data not shown). As PMSF and TLCK are inhibitors of serine peptidases and trypsin-like serine peptidases, respectively, these results indicate that the main peptidases detected by zymography in the female midgut are trypsin-like serine peptidases. Protein extracts from the female midgut were also reacted with the fluorogenic substrate Z-Phe-ArgAMC in the presence or absence of $5 \mathrm{mM}$ PMSF, $100 \mu \mathrm{M}$ TLCK, $100 \mu \mathrm{M}$ TPCK or $20 \mu \mathrm{M}$ E-64. These activities 

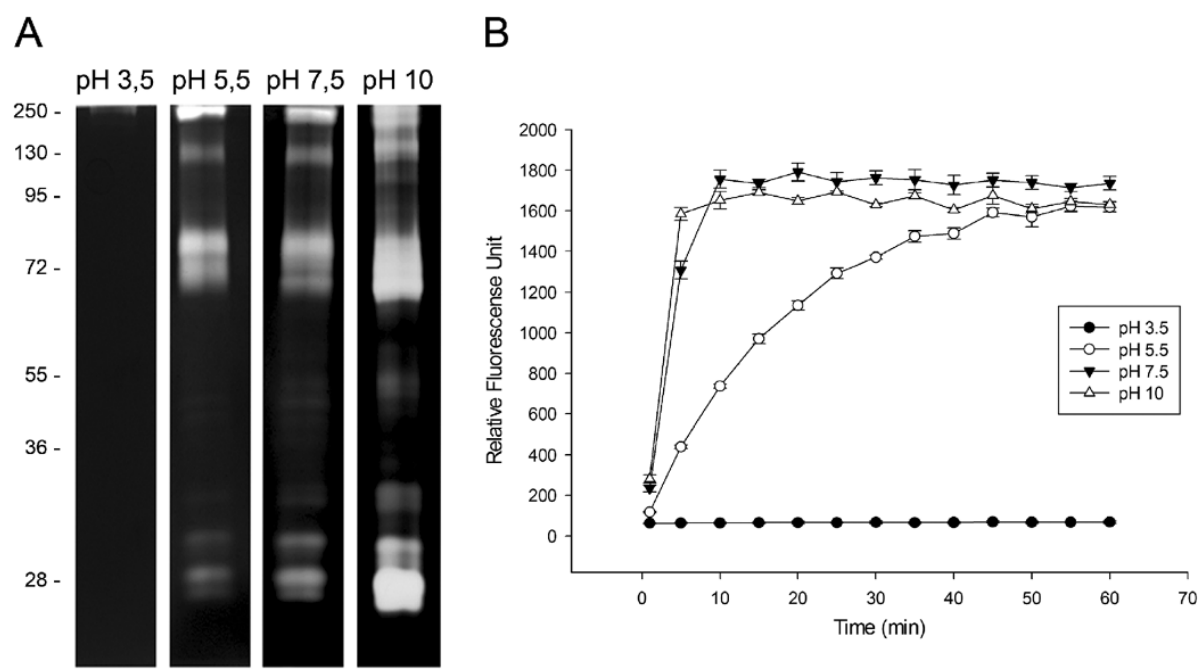

Figure 2 Influence of $\mathrm{pH}$ and temperature on the proteolytic profiles of the $\mathbf{A}$. albopictus midgut. The effect of pH on the proteolytic activities was evaluated by the incubation of protein extracts in $0.1 \mathrm{M}$ sodium acetate buffer $\mathrm{pH} 3.5$ or 5.5 or $0.1 \mathrm{M}$ Tris- $\mathrm{HCl}$ buffer pH 7.5 or 10.0 . (A) Zymographic gels incubated at $37^{\circ} \mathrm{C}$ for $12 \mathrm{~h}$. The numbers on the left indicate the apparent molecular masses of the peptidases (kDa). (B) In-solution assays performed using the fluorogenic substrate Z-Phe-Arg-AMC.

were again strongly inhibited by PMSF and TLCK, but not by ТРCK, (Figure 3B) corroborating the in-gel results. The occurrence of trypsin-like serine peptidases has been described in the larvae of $A$. aegypti and A. albopictus using both in-solution assays $[38,39]$ and zymographic analysis $[33,43]$. The main peptidases detected in other Diptera species also belong to the serine peptidase class $[42,44,45]$.
Trypsin-like serine peptidases and chymotrypsin were identified in the 2DE map of the $A$. albopictus female midgut

With the aim of identifying the peptidases detected in the zymographic assays, several protein spots resolved in the alkaline region of $2 \mathrm{D}$ gel maps from the $A$. albopictus female midgut previously obtained and reported by our group [33] were excised and analyzed by MS. Two protein

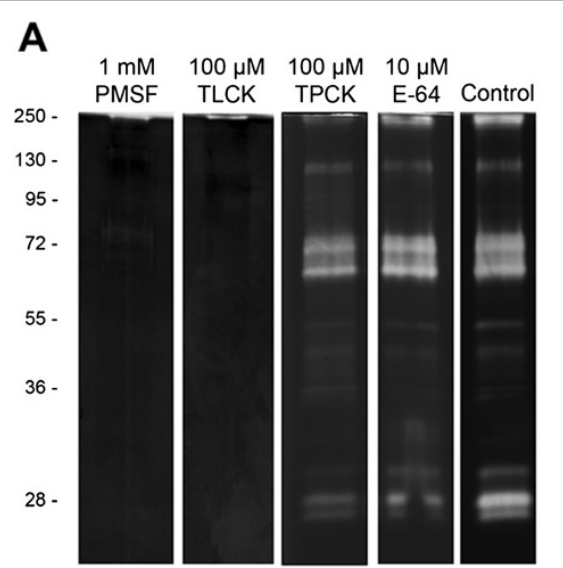

B

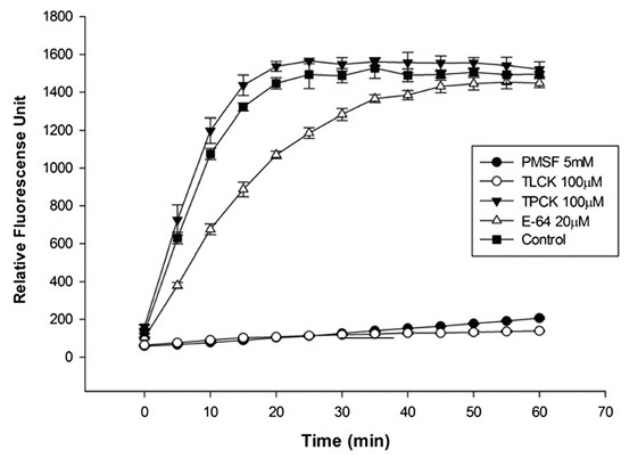

Figure 3 Effects of peptidase inhibitors on the proteolytic profiles of the A. albopictus midgut and quantitative in-solution assays for the proteolytic activities. (A) Samples were pre-incubated for $30 \mathrm{~min}$ in the presence of $1 \mathrm{mM}$ PMSF, $100 \mu \mathrm{M}$ TLCK, $100 \mu \mathrm{M}$ TPCK and $10 \mu \mathrm{M}$ $\mathrm{E}-64$. The proteolytic activities were detected after incubating the gels for $12 \mathrm{~h}$ at $37^{\circ} \mathrm{C}$ in Tris- $\mathrm{HCl}$ buffer, $\mathrm{pH} 7.5$. The control samples were processed in the same way but in the absence of inhibitors. The numbers on the left indicate the apparent molecular masses of the peptidases ( $\mathrm{KDa}$ ). (B) The in-solution assays were performed using the fluorogenic substrate Z-Phe-Arg-AMC in the absence (control) or presence of $5 \mathrm{mM}$ PMSF, $100 \mu \mathrm{M}$ TLCK, $100 \mu \mathrm{M}$ TPCK and $20 \mu \mathrm{M}$ E-64 in 100 mM Tris-HCl buffer, pH 7.5. 


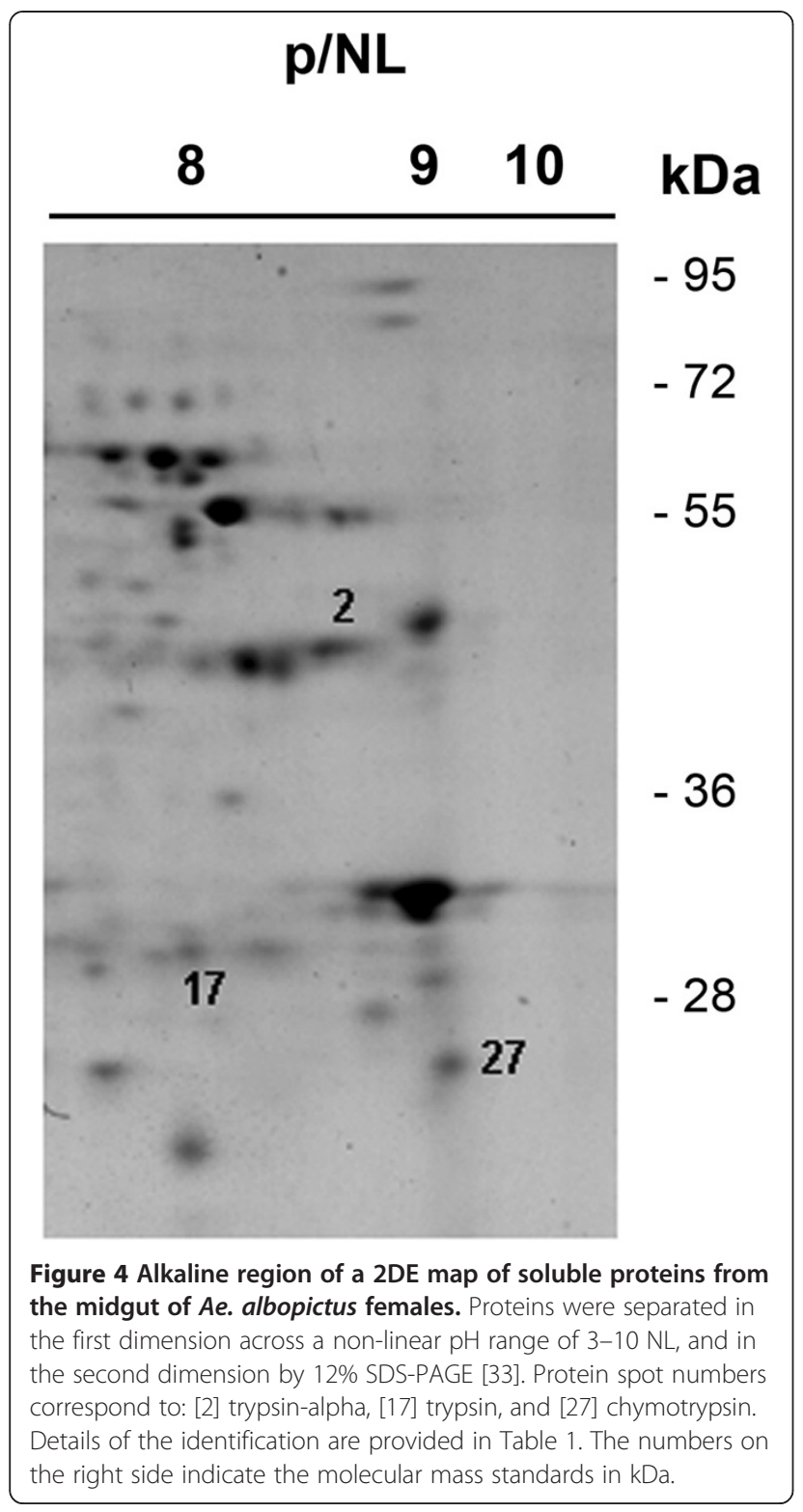

spots corresponding to trypsin alpha (AAEL008079) and trypsin (AAEL006425), respectively, and one spot corresponding to chymotrypsin (AAEL009680) were identified by their similarity to the $A$. aegypti sequences through the two search engines used for protein identification (Figure 4, Table 1). When the protein spots identified in the 2DE gel were compared to the proteolytic profile by $1 \mathrm{D}$ zymography, we observed that the molecular masses of peptidases identified by $2 \mathrm{DE}$ correspond to the apparent molecular masses of some of the proteolytic bands. The sequence alignment of both trypsin genes demonstrates very little similarity among the sequences. In addition, the peptide sequences identified by MS/MS for each gene are also different (Figure 5). Interestingly, while a chymotrypsin gene was identified by MS/MS in the midgut 2DE map, we did not observe this peptidase activity in the zymographic assays. This result may indicate that (i) this enzyme is expressed in the midgut of sugar-fed females but is not active under these conditions, i.e., it may be active only under blood feeding condition; or (ii) that, despite being expressed, the chymotrypsin is not active in the adult stage of the insect, i.e., this enzyme could be active only in other stages of the insect life cycle.

Although the A. aegypti genome has been reported to code for 380 trypsin-like serine peptidases, constituting one of the largest gene families in mosquitoes [22], the interrogation of the Vectorbase database using the words "trypsin" or "chymotrypsin" reveals only 80 coding genes for trypsin and 5 coding genes for chymotrypsin in the A. aegypti genome, among which are the genes identified here. As these peptidases are members of large gene families, it is difficult to ascertain which protein is expressed and active in a specific life cycle stage, in a specific tissue, under a specific condition. Therefore, we cannot rule out the possibility that other proteases, such as chymotrypsin, could be expressed in their active form in the midgut of blood feeding females. Our study shows the potential value of proteomic approaches combined with zymographic analysis for the identification and localization assignment of specific gene products.

Table 1 Aedes albopictus midgut peptidases automatically identified using the Mascot software

\begin{tabular}{|c|c|c|c|c|c|c|c|c|c|c|}
\hline $\begin{array}{l}\text { Spot } \\
\text { code }\end{array}$ & Protein name & $\begin{array}{c}\text { NCBI } \\
\text { Accesion } \\
\text { No. }\end{array}$ & $\begin{array}{l}\text { VectorBase } \\
\text { DB No. }\end{array}$ & $\begin{array}{l}\text { Theor/ } \\
\text { Exp MW }\end{array}$ & $\begin{array}{l}\text { Theor/ } \\
\text { Exp p/ }\end{array}$ & $\begin{array}{l}\text { Matching pep./ } \\
\text { Pep. identified by } \\
\text { MS/MS }\end{array}$ & Peptide sequence & $\begin{array}{c}\text { Error } \pm \\
\text { ppm }\end{array}$ & $\begin{array}{l}\text { Protein } \\
\text { score }\end{array}$ & $\begin{array}{l}\text { lon } \\
\text { score }\end{array}$ \\
\hline 27 & $\begin{array}{l}\text { Chymotrypsin, } \\
\text { putative } \\
\text { [Aedes aegypti] }\end{array}$ & $\begin{array}{c}\text { gil } \\
157123854\end{array}$ & AAEL009680 & $26.5 / 25.8$ & $9.0 / 9.3$ & $1(1)$ & R.SNELQTLYQK.T & 3 & 64 & 64 \\
\hline 2 & $\begin{array}{l}\text { Trypsin-alpha, } \\
\text { putative } \\
\text { [Aedes aegypti] }\end{array}$ & $\begin{array}{c}\text { gil } \\
157117906\end{array}$ & AAEL008079 & $32.1 / 40.8$ & $8.0 / 8.8$ & $1(1)$ & K.GACNGDLGGPLVCDAR.L & 3 & 78 & 78 \\
\hline 17 & $\begin{array}{l}\text { Trypsin } \\
\text { [Aedes aegypti] }\end{array}$ & $\begin{array}{c}\text { gil } \\
157113343\end{array}$ & AAEL006425 & 29.6/29.6 & $8.6 / 8.2$ & $1(1)$ & R.IVGGFEIDITDAPHQVSLQSR.G & 4 & 106 & 106 \\
\hline
\end{tabular}


9. Bartoszewska M, Williams C, Kikhney A, Opaliński Ł, van Roermund CW, de Boer R, Veenhuis M, van der Klei IJ: Peroxisomal proteostasis involves a Lon family protein that functions as protease and chaperone. J Biol Chem 2012, 287:27380-27395.

10. Weidlich S, Huster J, Hoffmann $\mathrm{KH}$, Woodring J: Environmental control of trypsin secretion in the midgut of the two-spotted field cricket, Gryllus bimaculatus. J Insect Physiol 2012, 58:1477-1484.

11. Wolfson $J \mathrm{~L}$, Murdock LL: Diversity in digestive proteinase activity among insects. J Chem Ecol 1990, 16:1089-1102.

12. Felix CR, Betschart B, Billingsley PF, Freyvogel TA: Post-feeding induction of trypsin in the midgut of Aedes aegypti is separable into two cellular phases. Insect Bioch 1991, 21:197-203.

13. Barillas-Mury C, Wells MA: Cloning and sequencing of the blood meal-induced late trypsin gene from the mosquito Aedes aegypti and characterization of the upstream regulatory region. Insect Mol Biol 1993, 2:7-12.

14. Kalhok SE, Tabak LM, Prosser DE, Brook W, Downe AE, White BN: Isolation, sequencing and characterization of two CDNA clones coding for trypsin-like enzymes from the midgut of Aedes aegypti. Insect Mol Biol 1993, 2:71-79.

15. Jiang $Q$, Hall $M$, Noriega FG, Wells M: cDNA cloning and pattern of expression of an adult, femalespecific chymotrypsin from Aedes aegypti midgut. Insect Biochem Mol Biol 1997, 27:283-289.

16. Bian G, Raikhel AS, Zhu J: Characterization of a juvenile hormone-regulated chymotrypsin-like serine protease gene in Aedes aegypti mosquito. Insect Biochem Mol Biol 2008, 38:190-200.

17. Polgár L: The catalytic triad of serine peptidases. Cell Mol Life Sci 2005, 62:2161-2172

18. Rawlings ND, Barrett AJ: Families of serine peptidases. Meth Enzymol 1994, 244:19-61.

19. Craik CS, Largman C, Fletcher T, Roczniak S, Barr PJ, Fletterick R, Rutter WJ: Redesigning trypsin: alteration of substrate specificity. Science 1985 228:291-297.

20. Terra WR, Ferreira C: Insect digestive enzymes: properties, compartmentalization and function. Comp Biochem Physiol 1994, 109:1-62.

21. Barrett AJ: Bioinformatics of proteases in the MEROPS database. Curr Opin Drug Discov Devel 2004, 7:334-341.

22. Venancio TM, Cristofoletti PT, Ferreira C, Verjovski-Almeida S, Terra WR: The Aedes aegypti larval transcriptome: a comparative perspective with emphasis on trypsins and the domain structure of peritrophins. Insect Mol Biol 2009, 18:33-44.

23. Noriega FG, Pennington JE, Barillas-Mury C, Wang XY, Wells MA: Aedes aegypti midgut early trypsin is post-transcriptionally regulated by blood feeding. Insect Mol Biol 1996, 5:25-29.

24. Wu DD, Guo-Dong W, Irwin DM, Zhang YP: A profound role for the expansion of trypsin-like serine protease family in the evolution of hematophagy in mosquito. Mol Biol Evol 2009, 26:2333-2341.

25. Borovsky D, Schlein Y: Quantitative determination of trypsin-like and chymotrypsin like enzymes in insects. Arch Insect Biochem Physiol 1988, 8:249-260

26. Gorman MJ, Paskewitz SM: Serine proteases as mediators of mosquito imune responses. Insect Biochem Mol Biol 2001, 31:257-262.

27. Noriega FG, Wells MA: A molecular view of trypsin synthesis in the midgut of Aedes aegypti. J Insect Physiol 1999, 45:613-620.

28. Shahabuddin M, Kaslow DC: Biology of the development of Plasmodium in the mosquito midgut: a molecular and cellular view. Bull Inst Pasteur 1994, 92:119-132.

29. Telleria EL, Araújo APO, Secundino NF, d'Avila-Levy CM, Traub-Csekö YM: Trypsin-like serine proteases in Lutzomyia longipalpis - expression, activity and possible modulation by Leishmania infantum chagasi. PLOS One 2010, 5:e10697.

30. Shahabuddin M, Lemos FJ, Kaslow DC, Jacobs-Lorena M: Antibody-mediated inhibition of Aedes aegypti midgut trypsins blocks sporogonic development of Plasmodium gallinaceum. Infect Immun 1996, 64:739-743.

31. Broadwell AH, Baumann P: Proteolysis in the gut of mosquito larvae results in further activation of the Bacillus sphaericus toxin. Appl Environ Microbiol 1987, 53:1333-1337

32. Lau YS, Sulaiman S, Othman H: The effectiveness of Trypsin Modulating Oostatic Factor (TMOF) and combinations of TMOF with Bacillus thuringiensis against Aedes aegypti larvae in the laboratory. Iran J Arthropod-Borne Dis 2011, 5:13-19.
33. Saboia-Vahia L, Borges-Veloso $A$, Cuervo $P$, Junqueira M, Mesquita-Rodrigues $C$, Britto C, Domont GB, De Jesus JB: Protein expression in the midgut of sugar-fed Aedes albopictus females. Parasit Vectors 2012, 5:290.

34. Galán JE, Pace J, Hayman MJ: Involvement of the epidermal growth factor receptor in the mammalian cells by Salmonella typhimurium. Nature 1992, 357:588-589.

35. Geer LY, Markey SP, Kowalak JA, Wagner L, Xu M, Maynard DM, Yang X, Shi W, Bryant SH: Open mass spectrometry search algorithm. J Proteome Res 2004, 3:958-964

36. Specht M, Kuhlgert S, Fufezan C, Hippler M: Proteomics to go: Proteomatic enables the user-friendly creation of versatile MS/MS data evaluation workflows. Bioinformatics 2011, 27:1183-1184

37. Suzek BE, Huang H, McGarvey P, Mazumder R, Wu CH: UniRef: comprehensive and non-redundant UniProt reference clusters. Bioinformatics 2007, 23:1282-1288.

38. Ho BC, Khoo HG, Chew LM, Wong KP, Ewert A: Food ingestion and digestive enzymes in larval Aedes aegypti and Aedes albopictus (Diptera: Culicidae). J Med Entomol 1992, 29:960-964

39. Yang YJ, Davies D: Trypsin and chymotrypsin during metamorphosis in Aedes aegypti and properties of the chymotrypsin. J Insect Physiol 1971, 17:117-131.

40. Borovsky D, Meola SM: Biochemical and cytoimmunological evidence for the control of Aedes aegypti larval trypsin with Aea-TMOF. Arch Insect Biochem Physiol 2004, 55:124-139.

41. Muhlia-Almazán A, Sánchez-Paz A, García-Carreño F: Invertebrate trypsins: a review. J Comp Physiol B 2008, 178:655-672.

42. Fazito-do-Vale V, Pereira MH, Gontijo NF: Midgut $\mathrm{pH}$ profile and protein digestion in the larvae of Lutzomyia longipalpis (Diptera: Psychodidae). J Insect Physiol 2007, 53:1151-1159.

43. Mesquita-Rodrigues C, Saboia-Vahia L, Cuervo P, Masini d'Avila Levy C, Alves-Honório N, Domont GB, De Jesus JB: Expression of Trypsin-like serine peptidases in préimaginal stages of Aedes aegypti (Diptera: Culicidae). Arch Insect Biochem Physiol 2011, 76:223-235.

44. Tabouret $G$, Bret-Bennis $L$, Dorchies $P$, Jacquiet $P$ : Serine protease activity in excretory-secretory products of Oestrus ovis (Diptera: Oestridae) larvae. Vet Parasitol 2003, 114:305-314

45. Pires FA, Moya-Borja GE, Barreira JD, Pinho RT, Alves CR: The main proteinases in Dermatobia hominis second and third instars larvae are serine-proteinases. Vet Parasitol 2007, 145:326-331.

doi:10.1186/1756-3305-7-253

Cite this article as: Saboia-Vahia et al.: The midgut of Aedes albopictus females expresses active trypsin-like serine peptidases. Parasites \& Vectors 2014 7:253.

\section{Submit your next manuscript to BioMed Central and take full advantage of:}

- Convenient online submission

- Thorough peer review

- No space constraints or color figure charges

- Immediate publication on acceptance

- Inclusion in PubMed, CAS, Scopus and Google Scholar

- Research which is freely available for redistribution 